\title{
Reflections on Japanese-Brazilian Immigration through Narrative: An Interview with Oscar Nakasato
}

\author{
CECILY RAYNOR \\ McGill University
}

Oscar Nakasato is a professor of Linguistics and Literature at the Federal University of Technology in Paraná. Prior to his acclaimed novel, Nihonjin (2011), Nakasato published, "Olhos de Peri" and "Alô," in Contos at the University Festival of Literature in 1999. In 2003, his short-story "Menino na árvore" won the Secretary of Culture's Literary Contest for the State of Paraná. In 2011, Nakasato published his debut novel, Nihonjin, a work that went on to win the Benvirá Prize for Literature (2011), the Bunkyo Prize (2011), and the Jabuti Prize in the category of fiction (2012). In Nihonjin, he tells the story of Hideo Inabata, a Japanese man who moves to Brazil to start a new life. Narrated from the perspective of Hideo's grandson, the novel depicts immigration struggles in Brazil, as its protagonists grapple with their increasingly hybrid identities across three generations. In this interview, Oscar Nakasato tells us what motivated him to write Nihonjin. He also discusses the extent to which his Japanese heritage impacted the plot, narrative style, and characters, and how he frames food and cultural differences as quintessential to the Japanese-Brazilian experience.

Raynor: Could you introduce yourself for us and discuss your Japanese background ${ }^{1}$

\footnotetext{
${ }^{1}$ The translation of this interview from Portuguese to English was carried out by my Research Assistant, Ms. Liz Wagner, a student of Hispanic Studies and English at McGill University.
} 
Nakasato: I am sansei, which means that I am the grandson of Japanese. My four grandparents came from Japan. Though I am the grandson of Japanese immigrants, my parents were already born here in Brazil. I was born in Maringa, a city in the north of the State of Paraná, where my mother went to give birth. That's why I am registered in Maringa, but I spent the first eight years of my life in a town in the Municipality of Floresta. When I was eight years old, my father, who was very concerned about providing his children with a better education given that there was only a rural school there, moved us to Maringa, where I spent most of my life. It's where I studied, where I did my degree in literature. Currently, I am a Professor at the Federal University of Technology in Paraná, which has a campus here in Apucarana, where I reside. I teach students who do an integrated technical degree, Literature, Introduction to Text, Grammar, and I advise upper-level students who are in other fields such as Engineering and Chemistry. The courses here are really diverse; I teach a course on Linguistic Communication, for example

Raynor: How did you become a writer?

Nakasato: Well, I guess I've always liked reading. Reading is not a tradition in my family, but I always enjoyed it. I remember that when I was a teenager, I had already taken to writing on old typewriters my parents owned. I even wrote a novel when I was around thirteen or fourteen years old, but I threw it out. It was actually very bad. I reread it a couple of years later and soon after, I threw it away. From then onward, when it was about time to start university, given my interest in reading, I went to study Law; I didn't even think about pursuing a Literature degree. You could study literature, but it was and still is a degree without prestige, unfortunately. That's why I chose to do Law so that I could be a lawyer, but I couldn't even hold out two years, dropped out of the program. Then I began Language Studies, with a focus on Literature. By the end of my degree, I began to really enjoy teaching and I eventually became a Professor. My degree has taught me linguistic and literary techniques, and I began to explore other novelistic genres, with which I was not familiar previously. So, even as early as my Master's program, I began participating in literary contests.

Raynor: What inspired your first novel?

Nakasato: I tend to write concisely, don't I? I like writing short texts. When I thought about the story of Nihonjin, I wanted to tell the story of an immigrant 
who came to Brazil. I wanted to tell the story of the children of that immigrant, of the grandchildren, and all of that didn't fit into a short story. That's why I decided to make it a novel.

Raynor: Did you chose to write this story as fictional testimony from the perspective of Hideo's grandson given that the testimonial genre is the most efficient method of telling this story?

Nakasato: I especially like first-person narratives because of their subjectivity. When I thought about the narrator and about writing fiction, I thought about telling Hideo's story, about the narrator I would choose to tell this story. My first option was Hideo, but since I was going to write in Portuguese, and Hideo, as an immigrant, would only have known minimal Portuguese, it couldn't be him. That's why I opted for his grandson, because I also wanted a narrator who would naturally have a certain proximity to the protagonist, but not too much. Thus, his position as grandson would allow him to play this role well, while remaining a bit outside of the story.

Raynor: You incorporated Japanese words into the narrative and didn't translate them. What motivated this decision?

Nakasato: Many people who have read my novel, even my aunt, have said, "Ah, you should add a glossary at the of the book for the Japanese words." Instead, I added a Japanese word here and there, and insisted on not translating them. I wanted readers to make contact with Japanese culture and language. It's an important element, and I also think that the amount of Japanese words is not excessive and does not compromise the understanding of the story. I think this was an interesting choice because you usually have a glossary at the end of the text, but not here.

Raynor: Was the novel's structure, written in short parts, intentional or did the idea emerge from your experience as a writer of short stories?

Nakasato: Yes, it was an intentional decision. At least that's what I thought. I remember a novel I read by an author called Autran Dourado, entitled, O risco do bordado, which has the same structure. The work is divided into six or seven chapters. Apart from having a certain sequence, it's not a story or novel I could read like a story, but I read it by chapters, each chapter equivalent to one story. 
The chapter ends and gives you the impression that you just finished a story. So that really influenced me, that structure. And of course, my experience with short stories has to have influenced that structure because I told the story step by step. I had already framed each chapter in a certain way that ended up framing the novel.

Raynor: Within contemporary Brazilian literature, there has been a historical lack of literary production written by and about Japanese-Brazilians. Do you think that this tendency is shifting with novels such as Nihonjin?

Nakasato: Well, I guess that the presence of Japanese-Brazilian protagonists as well as authors has been minor because of the adaptation process of Japanese immigrants and their offspring into Brazilian culture. The insertion of Japanese immigrants has been slower, of course, than that of Italians, Germans and the Spanish, simply because of differences in their culture of origin. This is also true in the case of language. My four grandparents, all of whom have now passed away, did so without ever learning the Portuguese language, though they lived most of their lives in Brazil. Thus, for a long time, immigrants came here, they had children and then led very solitary lives. They had very little contact with Brazilians. I guess that there are only a few Japanese-Brazilian descendants who write about this phenomenon, right? And I also think that because of this isolation, Brazilians didn't really know a lot about us, about our culture and how we lived. As a result, writers didn't write stories with Japanese-Brazilian protagonists because they just didn't know us, they didn't know our people.

Raynor: Do you think that this has changed in the last ten years? Or is the presence of Japanese-Brazilian writers still minor in relative terms?

Nakasato: The presence is still minor but it is changing. Up until recently, it was quite difficult to even see Japanese-Brazilians in Language Studies. Now there is a growing interest in writing and in literature. Also, due to my novel, some people have gotten in touch with me, descendants of Japanese, who also write. It is simply that they still don't receive a lot of media presence. But yes, there are Japanese-Brazilians writing and yes, this tendency is changing. It's just that the change is quite slow. 
Raynor: Nihonjin follows the historical trajectory of a Japanese-family and does not end in the present-day, but rather in an ambiguous time frame. Was this decision motivated by your own experience?

Nakasato: Hideo Inabata, the protagonist, came to Brazil in the second decade of the twentieth century, between 1916 and 1920. Though the story does not end in a specific time frame, I envisioned it to be in the 1980 s, when many Japanese immigrants in Brazil went to Japan to work in factories. This happened from the 1980s onwards, though many descendants did not leave in the $80 \mathrm{~s}$ or $90 \mathrm{~s}$ either. So, the story can be contextualized through these historical cues. The narrator, Hideo Inabata's grandson, says in one chapter that he would go work in Japan, right? "Dekasseguis" is a term people used for foreigners that go to Japan to work as factory workers. So, that's the context. I thought of the $1980 \mathrm{~s}$, without pointing to a specific date.

Raynor: In the novel, the home-space undergoes a series of evolutions. How does the home reflect the cultural changes in the lives of these JapaneseBrazilian family members?

Nakasato: Let's think about it like this. The Japanese culture is like a tripod. The first pillar of this tripod is the family, the other two are work and education. That's why family has always been, and still is, an essential part of Japanese culture. When I wrote the novel, many memories of my prior homes, my aunts' and uncles' houses, the house I lived in after I had moved to Maringa, came back just like that, in a very intense way. So many of the scenes in which family members were dining came from my own childhood recollections, from these houses, from my aunts and uncles, from my father, both from the countryside and the city. Naturally, I also undertook sociological, anthropological and historical research to back up some of my own recollections. But the particular memory of the houses I lived in was very strong while writing this novel. There are more things that I integrated into it. For example, there is scene in which Hideo's son and Harú's brother, who is murdered, questions how the men in his home sit down around the table for dinner while the women serve them. When the men are done with dinner, the women may eat. This situation is one that is based on my research but did not happen in my home, but rather in my uncle's. 
Raynor: Why is this space particularly important for this set of JapaneseBrazilian protagonists?

Nakasato: I think this has a lot to do with the fact that Nihonjin tells a family story. It's about family: Hideo Inabata's family, about his children and his grandchildren. The prevalence of the domestic space is at the heart of that dynamic. That's why there are such strong presences in the novel because family relations are central to Japanese-Brazilian culture. Both the parents and the children and the tension between them are pertinent cultural aspects for the book.

Raynor: Japanese food practices are also at the heart of your work, frequently mentioned in contrast with Brazilian food culture. What role does food have in the context of this story?

Nakasato: Food is clearly present in many moments. In my research on immigration for the writing of the novel, one of the salient elements in these texts was the difficult relation immigrants had with food. A dish is more than just a dish and seasoning. Japanese traditionally eat a lot of fish and rice, but when they came to Brazil they would be obliged to eat beans with pork skin, which has a very strong flavor that they weren't used to. This caused a lot of anxiety, as illustrated in the first chapter of the novel. I also drew upon a lot of my own memories, as I belong to a family that has an intimate relationship to food. We spend a lot of time at table. Even today, for example, I go to my mother's house on Sundays and people sit down to drink coffee at four-thirty or five in the evening and stay until dinnertime. One person leaves to make dinner, and the others remain at the table. There is an exchange here of coffee and bread and then rice and soup. Growing up we mostly ate Japanese cuisine but it has integrated over time with Brazil. Even today, I eat in a traditionally Japanese way, though not as often. But when I was a child, it was more extreme. The only seasonings we had were Shoyu [soy sauce] and Ajinomoto.

Raynor: If we think about literature as capable of capturing representational space, how can this story illuminate some aspects of the Japanese-Brazilian experience?

Nakasato: I believe in the power of literature to illuminate reality. Literature is an interesting space in which to do exactly that. It goes beyond history or 
sociology. It elucidates the experience of a lived reality and is different from history. To tell the story of Nihonjin, I drew upon other fields such as sociology and anthropology, but I went beyond them. Hideo Inabata has an entirely historical background, with elements taken from history itself. At the same time, literature helps to explain this experience in multi-faceted ways. Many people don't know the history of Japanese-Brazilians, even the descendants of the Japanese, who often don't know their own history or that of their parents or grandparents. Nihonjin serves to enable this illumination I think.

Raynor: You didn't specify from where in Japan this family of your novel originates. Was it important to you to leave that non-specific?

Nakasato: The intention was precisely that, to talk about the history of Japanese immigrants in general, not to explain from which region they originate. For example, I could decide that Hideo Inabata came from Nagasaki, which is the region of my paternal grandparents. But I opted to not do that because I wanted to tell the broader story of Japanese immigrants.

Raynor: In the novel second and third generation protagonists move away from the traditional home space of their parents and grandparents. Why do you think that this process of moving away so important to the story you narrate?

Nakasato: When I wrote Nihonjin I wanted characters that would break away from Japanese cultural traditions. In the case of Nihonjin, two characters do this: Harú and Sumie, who are siblings. Sumie challenges the Japanese tradition of marrying within the Japanese community. It's one that has lasted for many decades, and even today, it is important to Japanese-Brazilians. The uncle I spoke of before, with regard to men sitting down and eating first, didn't accept that his children, and thus my cousins, would marry non-descendants. And as it happened, out of twelve children not a single married someone who was not of Japanese descent. At some point, however, I believe in the 1960s or 1970s, this Japanese tradition started to break down. In Sumie's case, this happens earlier. But I wanted a character that would reflect this phenomenon of miscegenation. This is also true for me because I married a woman who is not of Japanese descent.

Raynor: You also write about Sumie's return to her Japanese ex-husband's home, a type of circular process for her from integration to abandonment, to 
miscegenation with a Brazilian man in Rio and final a return to the Japanese home. This evolution is painful in many regards. Can you elaborate on this?

Nakasato: This is an important narrative moment despite the impossibility of her staying in the home of her ex-husband. She did not have the intention of remaining there but came out of concern for her Japanese children. As you will recall, her parents rejected her and shunned her from entering their traditionally Japanese home.

Raynor: How was your novel received within the Japanese-Brazilian community? You mentioned contact with Japanese-Brazilians interested in writing as a form of expression.

Nakasato: When I won the Benvirá Prize, I knew that that would have some repercussions. Indeed, a novel written by a Japanese-Brazilian author and about such a subject matter had never won an important prize before, a prize that was crucial for the history of our literature. Thus, I knew this would have an impact, but it exceeded anything I had imagined. A lot of people whom I didn't know reached out to me, generally via e-mail. They described how they were able to recognize themselves in the story. Then, I was sought out by Japanese-Brazilian entities. For example, after having won the Jabuti Prize last October, I dined twice at the Japanese Consul's home in Paraná. Sometimes they organize festivities at the Consul's house, and I attended two of the dinners there. Perhaps of greater importance is the fact that Nihonjin will be translated into Japanese. Interestingly, the translation will happen here in Brazil and not in Japan. The novel will be translated and edited into chapters here and published in a bi-monthly magazine. This is interesting precisely because it will be published in parts, and, as we discussed, the chapters give the notion of closure. In this way, it reminds me of short stories, so that is going to be fun.

Raynor: Congratulations.

Nakasato: I think the existence of a large enough Japanese-Brazilian community has been a huge advantage for my book, which has sold well. This is a community that emigrated from Japan to Brazil over 100 years ago. In 2008, we commemorated 100 years of Japanese immigration. Although most of the descendants are very well integrated into Brazilian culture, a big part of this community still preserves and revels in Japanese traditions. 